\title{
Trends in the development of systems for monitoring the state of water bodies and the development of a Geo-information system Dniester on the basis of an industrial loT
}

\author{
Leonid Zamikhovskyi ${ }^{1}$, Olena Zamikhovska², Mykola Nykolaychuk ${ }^{3}$, Ivan Levitskyi ${ }^{4}$ \\ Ivano-Frankivsk National Technical University of Oil and Gas \\ Karpatska, street 15, Ivano-Frankivsk, 76019 \\ 1'leozam@nung.edu.ua, orcid.org/0000-0002-6374-8580 \\ 2elenazam@meta.ua, orcid.org/0000-0003-0775-0472 \\ 3nmj_2010@ukr.net. orcid.org/0000-0001-6185-2272 \\ ${ }^{4}$ letis@ukr.net.orcid.org/0000-0001-6538-7734
}

Received 11.04.2021, accepted after revision 25.05.2021

https://doi.org/10.32347/uwt2021.11.1502

\begin{abstract}
The work shows that inadequate and untimely hydrological forecasting of the level of flood development leads to significant annual economic damage and loss of life. The latter requires constant control and monitoring of the state of water bodies, which is possible with modern automated control and monitoring systems. The analysis showed that the information and measurement systems (AIMS) for flood control, which are operated in Ukraine, their quantity, cost and technical characteristics do not provide the information necessary for predicting the development of floods.

Analysis of trends in the development of systems for automated control and monitoring of the state of water bodies showed that modern foreign systems that are at the stage of development or testing are based on the use of microcontrollers, "smart" converters of physical quantities, modern communication systems and Internet of Things technology, as well as the use of smartphones with a Raspberry Pi camera for determining the water level in rivers.

The development with the use of the industrial Internet of Things of the basic version of the geoinformation system for control and monitoring of the state of water bodies GIS-Dniester is given. The structure, components and functions of GIS-Dniester are considered. The tasks of organizing hardware and software for parameterizing and diagnosing "smart" converters, establishing a communication environment for industrial communication, developing algorithms for collecting, processing and transmitting data, studying the characteristics of measuring signals are being solved. The results of
\end{abstract}

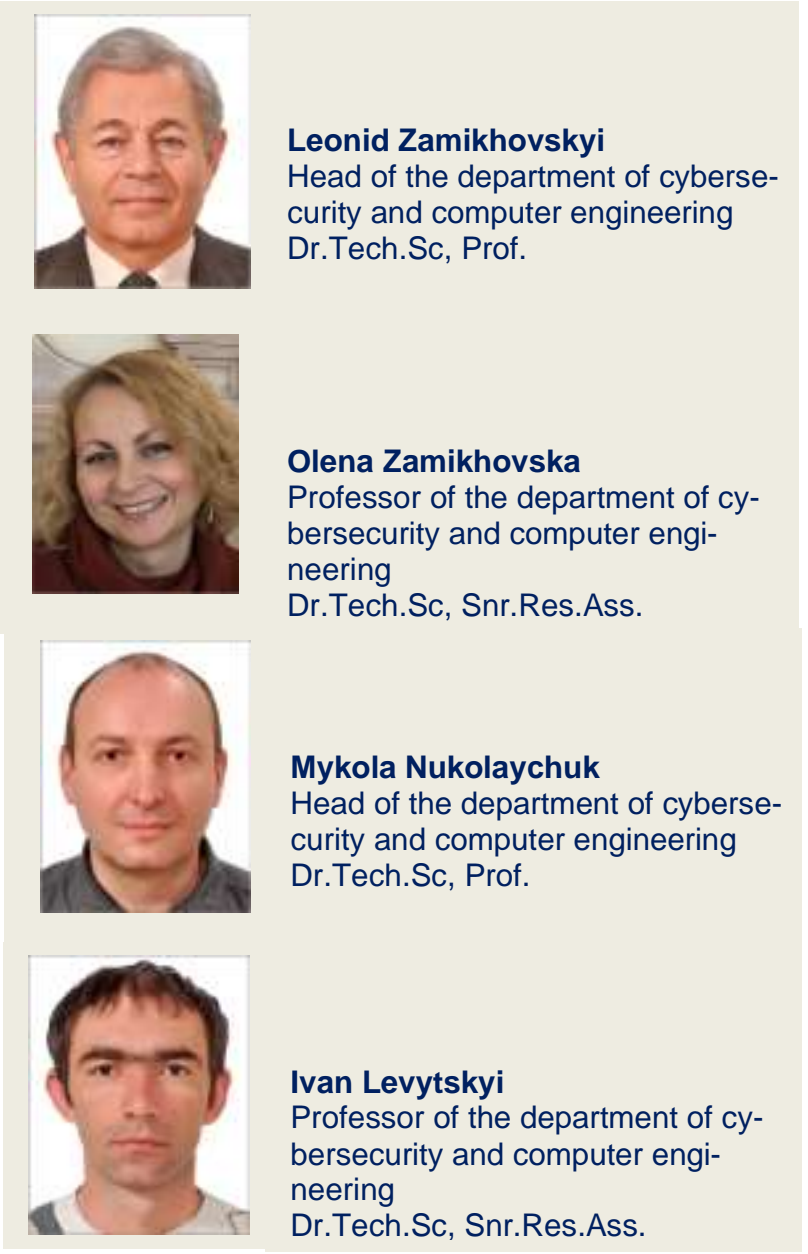

the study of the echo profiles of the XPS10 ultrasonic level sensor with "smart" -converters Multiranger 100 , as well as the procedure for working 
with the GIS-Dniester are presented. The use of the developed GIS-Dniester has shown its effectiveness and reliability in operation.

Keywords: geo-information system, industrial IoT, monitoring, flood control, microcontroller.

\section{INTRODUCTION}

Monitoring the state of water bodies is one of the main tasks of the modern development of the state. This is due to the fact that insufficient and untimely hydrological forecasting of the level of development of floods (floods), floods, mudflows, as well as the lack of a modern, fullfledged and integral protective complex lead to annual losses in the agricultural, industrial and social sectors of the economy, as well as human casualties.

There is practically no territory of the state where the negative impact of floods is not felt from time to time. Over the past 25 years, significant floods that led to emergencies were observed in 1995, 1997, 1998, 2001, 2008, 2019, 2020. As a result of the flooding of territories, for example, in the Ivano-Frankivsk region in 2000-2008, economic facilities and the population of the region were damaged in the total amount of more than 520 million. UAH.

At the same time, an increase in the accuracy of hydrological forecasting of both the level of flood development and the quality of work on accounting for land surface waters is possible if modern automated control and monitoring systems are available not only for the river water level, but also for other hydrological parameters. Hydrological posts should be equipped with such systems, which are developed on the basis of modern hardware and software. Today in Ukraine there is a significant number of different systems for monitoring the state of rivers, which are equipped with hydrological posts. Most of the systems have been developed by foreign firms on an element base, which are now outdated, and some of the systems are inoperable. Also known are some innovative developments of Ukrainian companies in the field of automation of systems for collecting information on the state of water bodies. At the same time, there is no information on the efficiency of operation of these systems, and the main development trends and requirements for modern control and monitoring systems for the state of water bodies have not been identified.

\section{THE AIM OF THE STUDY}

The purpose of the research is to determine the main trends in the development of systems for automated control and monitoring of the state of water bodies and the requirements for their structure and the development of a geoinformation system (GIS) for monitoring the state of river waters based on modern hardware and software, industrial Internet of things technology and research of one of the main sensors of the system. - XPS10 ultrasonic level sensor.

\section{RESULTS OF THE RESEARCH}

Modern GIS are located at hydrological posts and automatically transmit a set of parameters characterizing the hydrological characteristics of a water body (water level, water and ambient temperature, air humidity, atmospheric pressure, river flow velocity, chemical indicators, etc.). In this case, information about the specified parameters can be transmitted continuously or at regular intervals.

In [1], the existing methods and systems for forecasting the level of flood waters used and developed both in Ukraine and abroad are considered and analyzed. Automated control methods are considered, which are subdivided into direct (level sensors, automated measuring stations), as well as remote measurement methods, namely: space (satellite survey systems); airborne (airplanes, helicopters) and constitute a significant part of remote sensing data of types of surveys, methods of obtaining data using measuring systems in conditions of physical contact with the surveyed object.

It is concluded that the insufficient level of predictability of floods, floods and flooding, as well as the lack of a modern integral complex of protective measures lead to significant annual damage in the agricultural, industrial and social sectors of the economy, deterioration of the ecological state of the environment, which is also confirmed in [2,3]. Mathematical modeling of the flood process and methods of forecasting them based on statistical data are considered in [4]. The proposed models 
take into account, as one of the components, the soil moisture of the studied river basin.

An analysis of the existing AIMS for flood water control is given in [5]. The AIMS in Ukraine, which are in working order, at the stages of development or implementation, include: "TISA", "Prykarpattya", a computer system with autonomous sensors, "AKSON", a precipitation gauge and an integrated system of nationwide flood monitoring. A brief description of these systems is given and the main disadvantages of these systems are noted: high economic costs for the development and implementation of these systems and technical means (AIIS "Tisa" - 225 thousand Euro, 3 gauging station AIIS "Prykarpattya" 500 thousand UAH., AKSON - 600 thousand $\mathrm{UAH}$, an integrated system of nationwide flood monitoring - 14 million 680 thousand $\mathrm{UAH})$. Inadequate financing from the state does not allow the creation of a sufficient number of AIIS, gauging stations in order to warn about the occurrence of flood waters.

In [6], information is provided on the foreign experience of using remote hydrological posts, as well as a brief historical excursion to the development of automated observation systems in Ukraine. The control and information system developed by Satellite + LLC for automatic gauging stations of the BPV series, consisting of a water level sensor, a communication channel, a recording device and a power source, is considered in detail. The system uses a set of batteries and information transmission via the GPRS channel of one of the GSM operators. The presence of batteries indicates that information is transmitted discretely, after a certain period of time. However, the work [6] does not indicate the frequency of information transmission. While the rapid development of floods requires continuous information about changes in the level of water bodies.

The work [7] presents the results of the development and operation of automated technical complexes: an automated hydrometeorological station - AGMS - (manufacturer Tekhpribor LLC, Lviv, Ukraine) and an automatic system for hydrometeorological monitoring - Vaisala HydroMet TM MAWS100 (manufacturer - Vaisala Oyj ", Finland). It is indicated that their introduction significantly improves the efficiency of the forecasting organizations of the hydrometeorological service, and in the case of the formation of rapid floods in mountain annual basins, it is a necessary condition and guarantee of increasing the lead time and confirming hydrological forecasts and warnings.

In [8], a system for controlling the level of flood waters is proposed, the basis of which is an ultrasonic sensor for measuring the level and other sensors. The collection and transmission of information is carried out using the Arduino Uno and a wireless sensor network based on LoRa technology. The results of testing the proposed system are presented.

The use of the early warning systems for floods in the Indian Himalayas (The Early Warning Systems - EWS) is given in [9]. The flood monitoring system and EWS consists of base stations and a control center. The base station consists of a measurement module and a processing module that performs a localized forecast of the water level and transmits the predicted results and measured data to the control center. The Control Center uses a hybrid system of Adaptive Neuro-Fuzzy Inference System (ANFIS) and supervised machine learning, as well as a Linear Multiple Regression (LMR) model to predict water level. This hybrid system demonstrated high accuracy of $93.53 \%$ for daily forecasts and $99.91 \%$ for initial forecasts.

A prototype of a flood warning and monitoring system is described in [10]. Structurally, the system consists of three main blocks: a telemetry data collection unit; collecting data from sensors located on the river bank; data analysis and processing unit. It also includes the development of algorithms for processing data obtained from sensors, with the issuance of appropriate warnings to the public and control messages for spillways. The system also contains an information dissemination unit, which is used to alert the population about the level of flood risk. The system uses ESP32 development boards to collect data from sensors of precipitation, flow and water level in the river, which are integrated into an IoT monitoring system to transfer raw data using $4 \mathrm{G}$ devices connected to an ESP microcontroller. 
End users are also offered an Android app to track flood risk situations in real time. The above experimental results demonstrate the reliability of flood forecasting.

The use of the Internet of Things for monitoring the behavior of the state of the river, including the development of the IWT hardware (RiverCore), is discussed in [11]. A description of the developed web-based data collection platform integrated with IoT technologies for data transmission over $3 \mathrm{G}$ cellular networks is given. The developed architecture uses the Message Queuing Telemetry Transport (MQTT) protocol along with encryption and security mechanisms to send data packets in real time to the server, and stores the received data in a non-relational database. From there, the data can be accessed and displayed using a variety of query settings and graphical representations, which allows it to be used in the future in the flood analysis and forecasting system.

Flood Prediction Using Sensor Integrated based on Internet of Thing and Radio Frequency to Solve Environmental Issue (FRESTI) is described in [12]. The need to develop such a system for Indonesia is due to the fact that in 2015-16 there were 500 floods due to which in 2015115 people died and 317,683 people were displaced from flooded areas, and in 201675 people died and 105,301 people were displaced. The early flood detection function of FRESTI is achieved with built-in rain sensor, water flow, river slope and water level sensors. The measured parameters will allow assessing potential flooding and issue early warnings. FRESTI is equipped with a siren that responds to the receipt of data transmitted using radio frequencies. As a warning signal, these sirens will be located near the village. With the use of IWT, data from FRESTI on the state of the river in real time via the Internet can be obtained by interested people living in the flood zone.

In [13], it is proposed to use modern smartphones with built-in cameras, positioning sensors and powerful processors as measuring instruments for measuring the water level during floods. With the use of volunteered geographic information (VGI), the hydrological network of water meters can be highly compressed in space and time, even for watersheds that are currently not monitored. These are shallow streams and rivers that also need to be monitored to better understand what drives flood development and improve the reliability of their forecasting. Stationary lowcost solutions based on Raspberry Pi imaging systems are universal for continuous monitoring of hydrological parameters. The two complementary systems, the smartphone and the Raspberry Pi camera, use the same automatic water level detection methodology. The accuracy of water level measurement ranges from a few millimeters to several centimeters.

An expert system for forecasting floods based on web services, including a knowledge base with the ability to read data from sensors, such as precipitation, river flow, in real time, is considered in [14]. Its use will facilitate the monitoring of various influential factors that contribute to an increase in the level of flood waters in flood areas and, as a result, will allow decision-makers to take measures to prevent the occurrence of emergencies.

Based on the review of modern trends in the development of systems for automated control and monitoring of the state of water bodies, the following conclusions can be drawn:

- a number of existing systems for monitoring and forecasting the level of flood waters that are operated in Ukraine, such as TISA, Prykarpattya, AKSON, etc., physical properties of soils;

- domestic developments that use self-contained power sources do not allow continuous monitoring of the state of water bodies, which is especially important during floods;

- modern foreign systems under development or testing are based on the use of microcontrollers Arduino Uno, ESP, etc. to collect data from sensors, which are increasingly used as "smart" -converters of physical quantities. At the same time, microcontrollers are integrated with IoT technologies for data transmission via $3 \mathrm{G}$ and $4 \mathrm{G}$ cellular networks, allowing interested persons living in the area of possible flooding to track changes in the water level in the river via the Internet; 
- to predict the water level based on the processing of the received data from the sensors, a hybrid system of the ANFIS model and the LMR model is used, which makes it possible to increase the accuracy of forecasting the development of floods;

- the use of a smartphone and a Raspberry Pi camera, which use the same methodology for automatically determining the water level, will expand the water level control zone in streams and small rivers, and take into account their influence on the formation of the general level of flood waters.

Considering the above, a basic version of the geoinformation system for monitoring the state of water bodies "GIS-Dniester" was proposed on the basis of hardware and software from Siemens and "smart" converters - an ultrasonic level sensor XPS10 [15] together with "smart" converters Multiranger 100 [16].

\section{Purpose and composition of "GIS-Dniester"}

The developed system is designed for remote monitoring of the main meteorological parameters of the Dniester River waters and the environment at controlled points and transfer of measurement and visual data for their subsequent processing, visualization, documentation and long-term storage.

The system allows organizing local and central dispatching points and operates in real time.

The automated system includes the following components:

- server workstation based on IBM-PC;

- industrial and RZ-routers of the GSM standard for wireless industrial communication;

- programmable logic controller (PLC) SIMATIC S7-1200 "Siemens";

- signal modules SM for processing and digitizing output signals from sensors;

- communication equipment (power supplies, switches, connectors, cables, etc.);

- sensors of basic meteorological parameters;

- top-level software - SCADA-system (supervisory control and data collection system).

The system is designed as a single hardware and software complex with a distributed archi- tecture and is optimized for working with remote monitoring objects and local and central dispatch centers. GIS-Dniester is capable of performing any tasks related to collection, primary processing, transfer and storage of controlled parameters.

The hardware part of the system is based on the products of world manufacturers in the field of industrial automation and communications. The main control functions are implemented on the hardware and software of the Siemens concern.

The system is compatible with sensors with unified measurement signals from a wide range of manufacturers.

The communication network is implemented on the basis of VPN (Virtual Private Network) of the mobile operator "Kyivstar" of the GSM standard, provides access to technological equipment practically throughout the entire territory of Ukraine and protection from unauthorized access.

Application software has been developed for the controller and workstation, which adapts to the hardware configuration of a specific object. The dispatcher's dialogue with the system is implemented in the form of mnemonic diagrams (interface pages) in the SCADA system (Supervisory Control And Data Acquisition). Provided the functions of visualization, archiving, warning signaling of controlled parameters going beyond the permissible limits and documentation of monitoring parameters.

In the extended version of GIS-Dniester, it is possible to control additional parameters (water turbidity, flow rate, etc.).

Structurally, the main devices of the system are made according to a modular principle and are placed in a mounting container (Fig. 1), which does not include sensors and the dispatcher's workstation. The system is designed for continuous operation.

In the process of integrating "smart" converters into GIS-Dniester, it is necessary to solve the problems of organizing hardware and software for parameterizing and diagnosing "smart" converters, establishing a communication environment for industrial communication, developing algorithms for collecting, processing and transmitting data, studying the 
characteristics of measuring signals, also research of information processes in such systems $[17,18]$. The study of the echo profiles of ultrasonic signals from the XPS10 transducer was carried out on the basis of the DELPHIN PLUS V1.5 instrumentations [19].

Fig. 2 shows the results of the parameterization of the ultrasonic "smart" level transducers Multiranger 100 with the XPS10 sensor.

In Fig. $3-5$ the results of the investigation of the echo profiles of the XPS10 ultrasonic level sensor with the Multiranger 100 "smart" transducer are unknown. The XPS10 sensor is installed in a special container and mounted on the bridge over the Dniester river in Galich over the middle of the river bed. The distance from the sensor to the water surface was $10 \mathrm{~m}$.

At the output of the "smart"-converter Multiranger 100, a unified current signal (4...20 $\mathrm{mA}$ ) is generated, fed to the PLC S7-1200 [20], where it is digitized, normalized and scaled for further use as part of GIS-Dniester.

Analysis of the echo profiles of the XPS10 ultrasonic level sensor showed that the reliability of the correct reception of the signal reflected from the water surface depends on many factors (water and air temperature, humidity, the presence of various kinds of electromagnetic interference and building structures).

The system implements the ability to re-

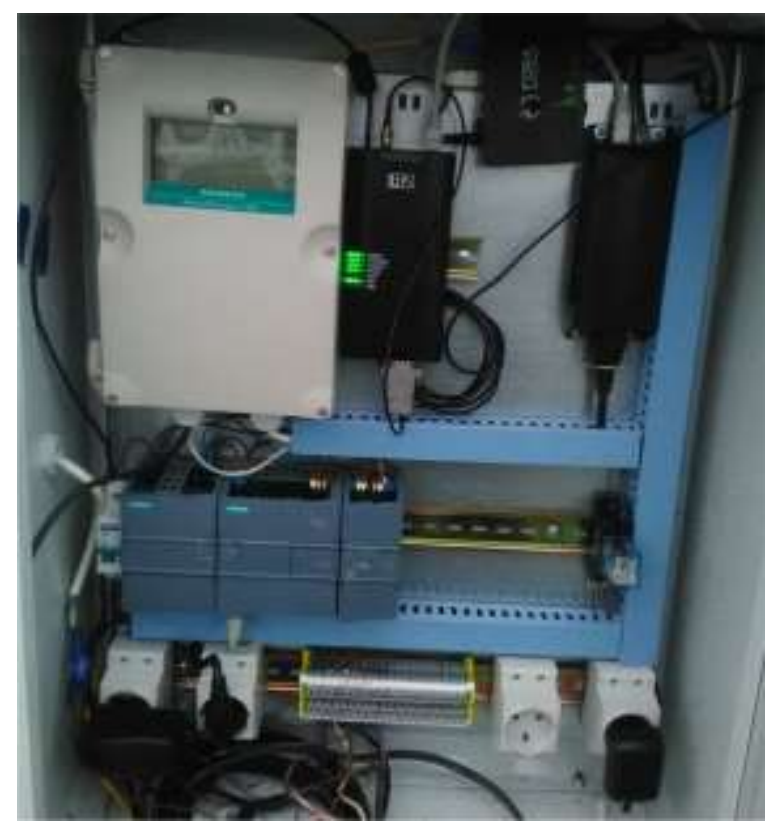

Fig. 1. Exterior view of the mounting container GIS-Dniester motely read the echo profiles of the XPS10 ultrasonic level sensor, which made it possible to analyze a large number of echo profiles under various environmental conditions, and therefore select the optimal parameters and operating modes for the XPS10 ultrasonic level sensor and the Multiranger 100 "smart" transducer.

As a result of the research, the functionality of the GIS-Dniester was expanded, including by blocking individual components of the echo profiles that arise due to structural obstacles when measuring the water level, which made it possible to increase the accuracy of the results.

The hardware configuration of the S7-1200 PLC was carried out in the TIA Portal V14 software environment in the "run-time" mode (see Fig. 5), which includes:

- Project tree - project tree "Galich_1_PLC_Sensor_060421_1";

- hardware PLC S7-1200 (PLC_1, AI 4x13BIT_1, AI 4x13BIT_1)

- hardware catalog - hardware catalog.

In Fig. 6 shows a fragment of the application in the FBD (Functinal Block Diagram) language, which implements the algorithm for processing the initial measuring signal from the MultiRanger 100 level transducer in the TIA Portal V14 software environment in the "run-time" mode. The program includes the following program instructions for processing

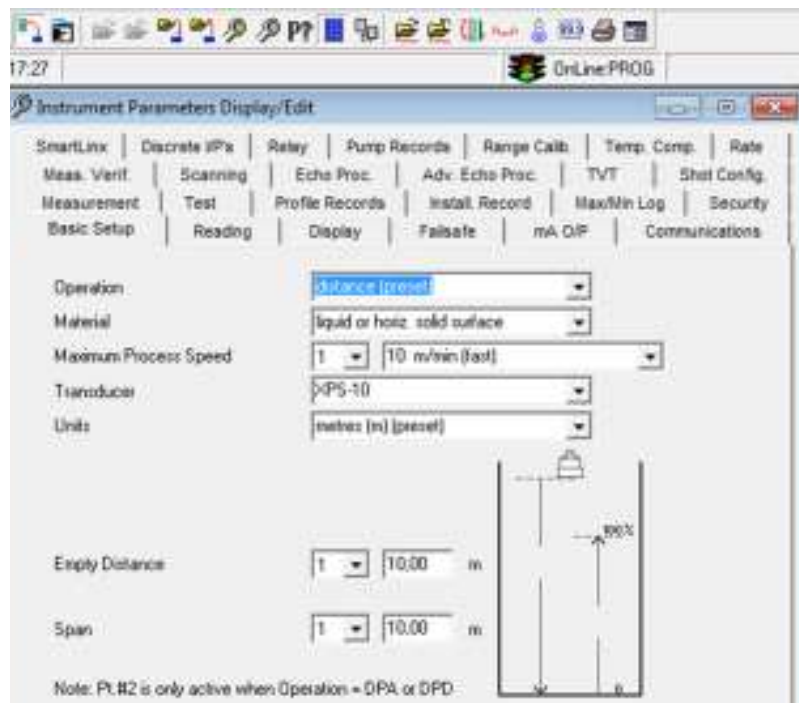

Fig. 2. Parameterization results of the ultrasonic "smart" level transducers Multiranger 100 with XPS10 sensor 


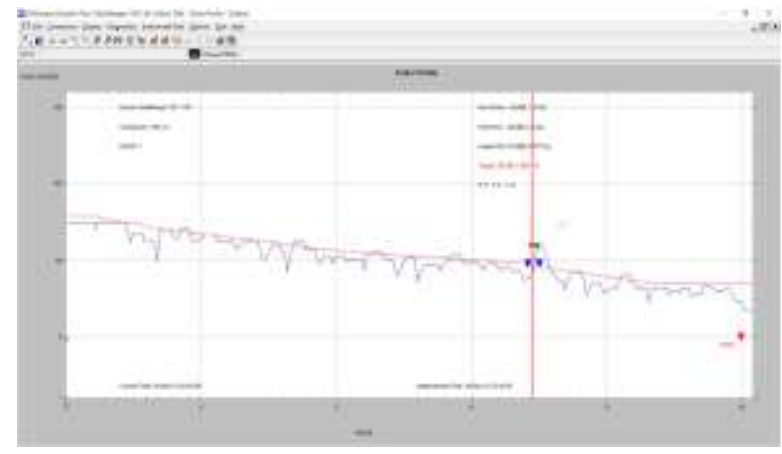

Fig. 3. Echo profile of the XPS10 ultrasonic level sensor (correctly defined echo profile of the reflected signal with a L level of $9 \mathrm{~dB}$ )

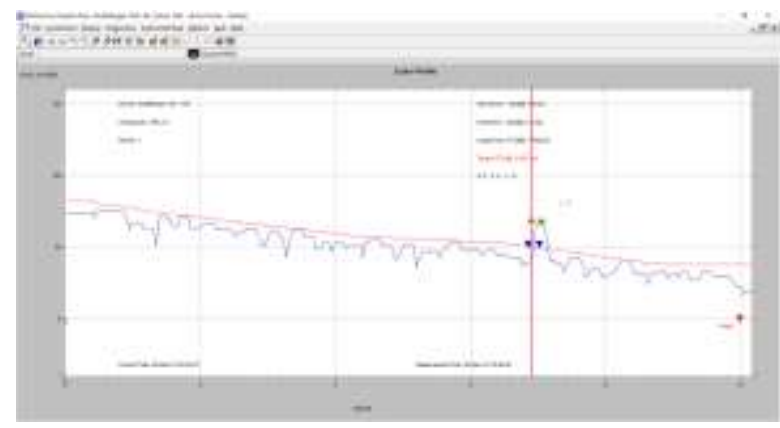

Fig. 4. Echo profile of the XPS10 ultrasonic level sensor (correctly defined echo profile of the reflected signal with level L: $17 \mathrm{~dB}$ )

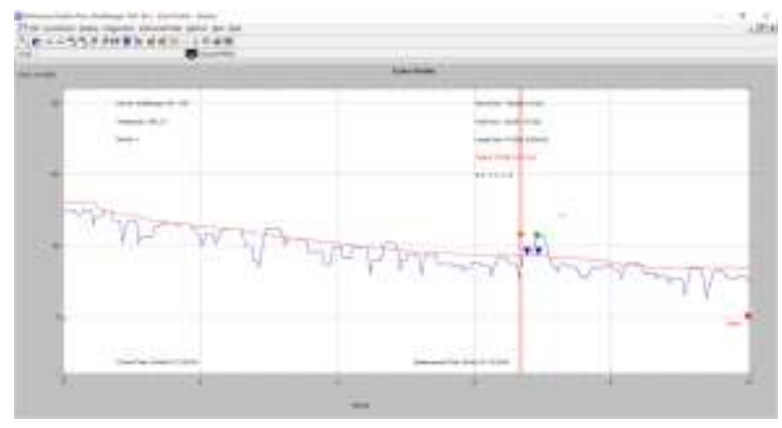

Fig. 5. Echo profile of the XPS10 ultrasonic level sensor (the echo profile of the reflected signal with a $L$ level of $9 \mathrm{~dB}$ is incorrectly determined)

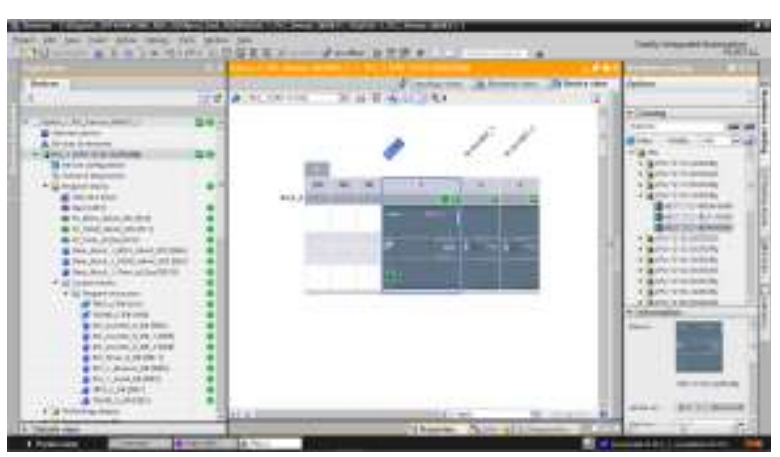

Fig. 6. Hardware configuration of the S7-1200 PLC in the TIA Portal V14 software environment in the "run-time" mode

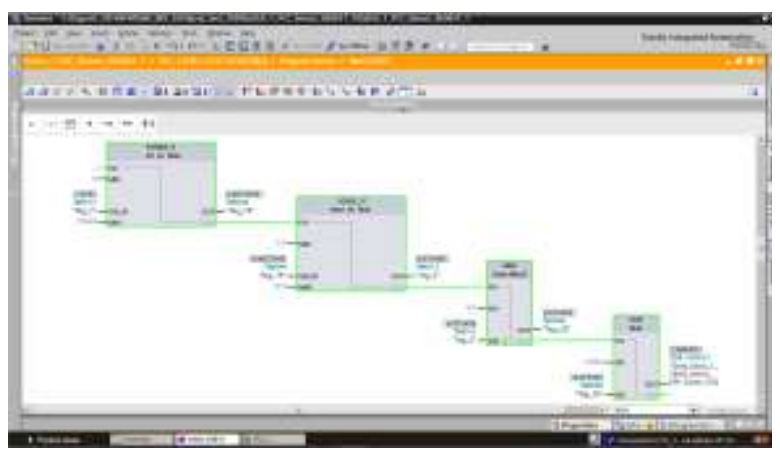

Fig. 7. Fragment of an application in the FBD language that implements the signal processing algorithm from the MultiRanger 100 level transducer in the "run-time" mode

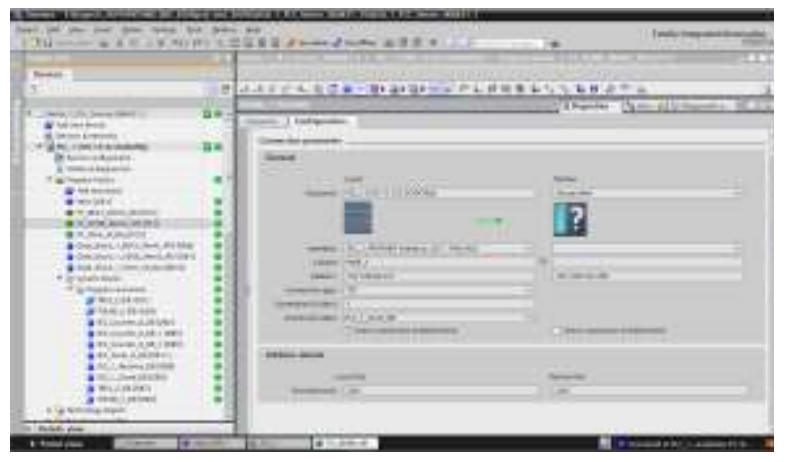

Fig. 8. Procedure for parameterizing the communication connection between the local monitoring station and the server 
and calculating the absolute value of the water level in the Dniester River:

- NORM_X - normalizing function, converts the digitized value of the measured distance signal from the level sensor in the plane of the monitored object within (0-27648 relative units) into a floating point value within $(0.0 \ldots 1.0)$;

- SCALE_X - scaling function, converts the normalized value of the measured signal into the absolute value of the monitored parameter (distance from the level sensor of the plane of the monitored object), taking into account the measuring range of the XPS10 level sensor and the MultiRanger 100 transmitter within $(0 \ldots 10 \mathrm{~m})$;

- ADD - function of linear correction of the absolute value of the controlled parameter;

- SUB - subtraction function, which converts the measured distance to the controlled object into a level (the level of the Dniester river in Galich_1).

Fig. 7 shows the procedure for parameterizing the communication connection between the local monitoring station and the server.

In Fig. 8 shows a fragment of an application in the FBD language that implements the process of transferring data from a local monitoring station to a dispatch server.

A dispatcher's workstation is installed in the central control room, which provides monitoring of remote objects.

After activation of the corresponding object of control (for example, Galich_1), the window of the main page of GIS-Dniester is displayed on the screen (Fig. 9).

The main part of the main interface page contains the following components:

- a field of archives in the form of trends in the main meteorological parameters of the Dniester River waters and the environment with scales of the corresponding color and time scale;

- buttons for switching to other pages of the interface;

- current monitoring parameters;

- archive monitoring parameters;

- scales of current parameters;

- tools for managing the field of archives;

- system time;

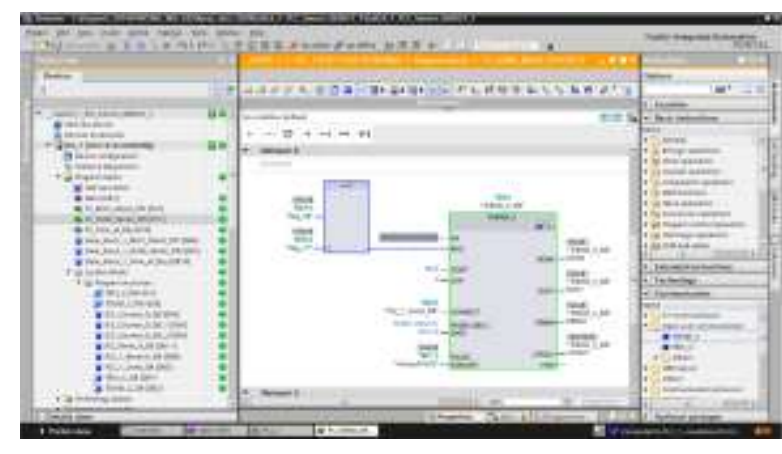

Fig. 9. Fragment of an application program that implements the process of transferring data from a local monitoring station to a dispatch server

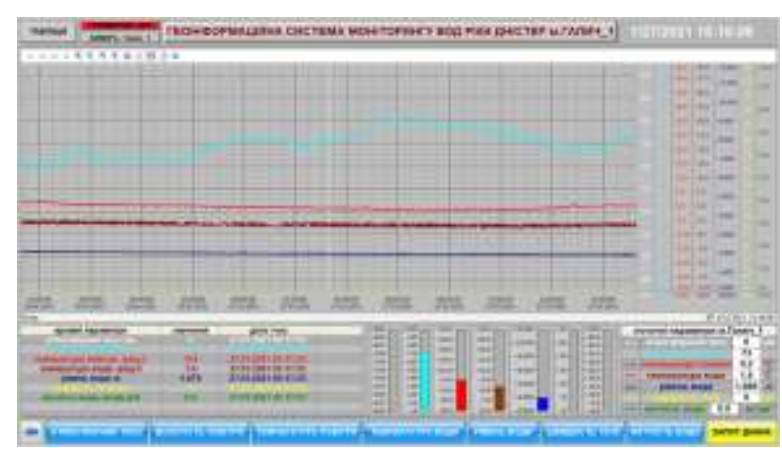

Fig. 10. Monitoring system main page window

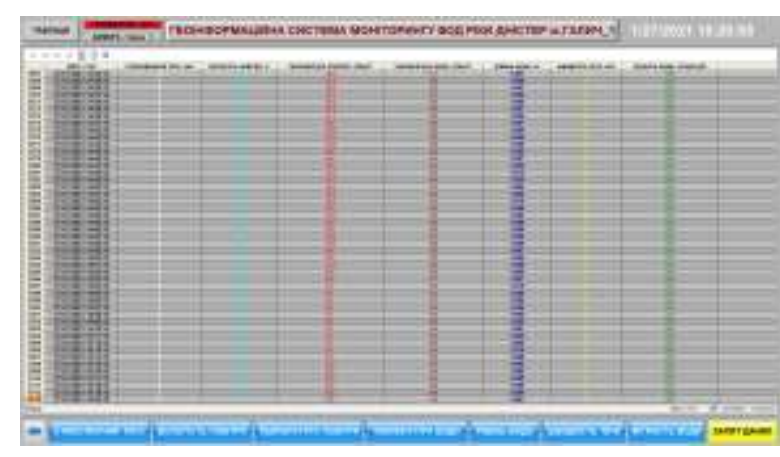

Fig. 11. Tabular archive of the main meteorological GIS-Dniester

- marker of archive parameters (movable vertical white line).

Other pages of the monitoring system interface contain information in accordance with the monitored parameter:

- air humidity (blue trend - from 0 to $100 \%$ );

- air temperature (red trend - from -30 to $\left.+50^{\circ} \mathrm{C}\right)$; 
- water temperature (dark red trend - from -10 to $+30^{\circ} \mathrm{C}$ );

- water level (blue trend - from 0 to $12 \mathrm{~m}$ ).

To go to the previous values of the archives, you must activate the "pause" button 밈.

Further, the dispatcher can use the movement tools to view and scale to refine the archived parameters at appropriate time intervals.

To go to the main page of the GIS-Dniester interface, you must activate the navigation button 4

To go to the tabular archive, use the "table" button Tasnuss. The tabular archive window (Fig. 10) is intended for archiving tabular values with a selected time interval. The window interface allows viewing the archives of meteorological parameters. The first column displays the record number, the second - the date and time of the recording, all the rest - the corresponding archive parameters. To view the previous values of tabular archives, you must activate the "pause" button and use the "scroll" tool to go to the required date and time.

In addition, the developed GIS-Dniester is equipped with a HIKVISION DS-2CD2010F-I video camera, which is installed on the support of an old bridge in the city of Galich, allows for visual control of the level of the Dniester River through a video surveillance subsystem (Fig.11, 12).

\section{CONCLUSIONS}

Automated systems for monitoring and control of water bodies that are in working condition, at the stages of development or implementation, do not provide hydrometeorological monitoring of the state of water bodies in Ukraine due to their small number, high cost and technical characteristics that do not correspond to the modern level. Inadequate funding from the state does not allow the creation of a sufficient number of modern monitoring systems, reduces the effectiveness of the forecasting organizations of the hydrometeorological service to prevent emergencies caused by the development of floods.
Modern trends in the development of systems for automated control and monitoring of the state of water bodies are aimed at the use of "smart" -converters of physical quantities, microcontrollers such as Arduino Uno, ESP, etc., which are integrated with IoT technologies for data transmission through wireless sensor networks based on LoRa technology and cellular 3G and 4G networks; modern smartphones with built-in cameras, positioning sensors and powerful processors, with a Raspberry Pi camera allow automatic water level detection. The use of IWT technologies

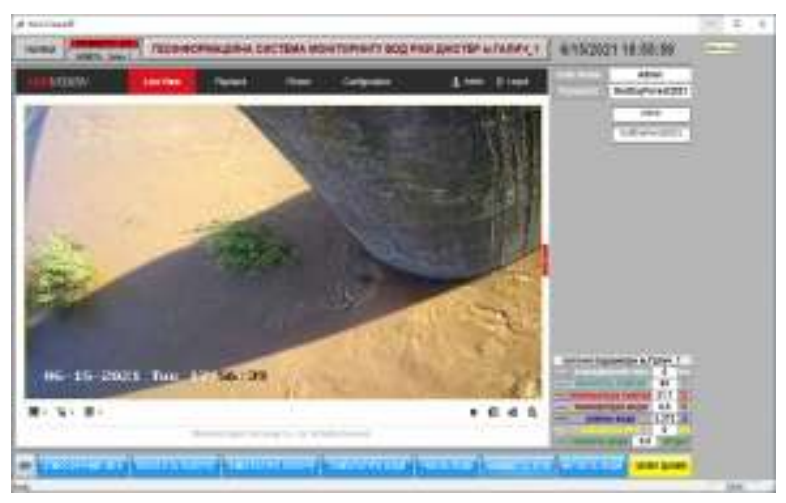

Fig. 12. Visual control over the level of the Dniester river through a video surveillance subsystem dated 06.15.2021

will allow interested persons living in the zone of possible flooding to monitor changes in the level of water bodies via the Internet and make appropriate decisions.

The proposed structure of GIS-Dniester based on industrial ICT with the use of modern hardware and software and "smart"-converters and a video camera, which made it possible to provide visual control over the level of the Dniester River. The purpose of GIS-Dniester, the main components and the principle of its operation are considered. Due to modularity and unification, the basic GIS - Dniester can be expanded or modernized and supplemented with other types of sensors.

The results of the study of the echo profiles of the XPS10 ultrasonic level sensor with Multiranger 100 "smart" converters, which made it possible to increase the accuracy of water level measurement, were considered, the hardware configuration of the S7-1200 PLC in the TIA Portal V14 software environment was carried 
out in the "run-time" mode and the fragment applications in the FBD (Functinal Block Diagram) language, which implements the algorithm for processing the original measuring signal from the MultiRanger 100 level transducer. The use of the developed GIS-Dnister has shown its efficiency and reliability in operation.

\section{REFERENCES}

1. Zamikhovskyi L.M., Klapoushchak O.I., 2011. Analysis of methods and systems for monitoring and forecasting the level of flood waters. Oil and Gas Energy: All-Ukrainian Scientific and Technical Journal, Vol.2 (15), 99-105. ISSN 1993-9868 (in Russian).

2. Yevhen Gorbatenko, Irina Bratasyuk, Vladimir Sharov, 2015. Mobile building is in coastal hydraulic engineering. Underwater Technologies, Vol.01, 23-33 (in Russian).

3. Yevhen Klushnychenko, Iryna Savchuk, 2020. The use of geographical and informational systems the provision state and public interests in the implementation of urban development. Underwater Technologies, Vol.10, 66-74.

4. Zamikhovskii L.M., Oliinyk A.P., Klapoushchak O.I., Shtaiyer L. O., 2014. The flood process mathematical modelling an their prediction methods based on static data. Life Science Journal No. 8s, 473-477. ISSN 1097-8135 (Print) / ISSN: 2372-613X.

5. Klapoushchak O.I., 2012. Analysis of existing automated information and measuring systems for flood control. Scientific news of the Galician Academy, Vol. 2 (22), 36-44. ISSN 2225-9716 (in Ukrainian).

6. Serebryanskyi D.V., Kravchynskyi R.L., 2012. Automation of the system for collecting and analyzing data on the state of water bodies in Ukraine: Current state and prospects. Hydrology, hydrochemistry, and hydroecology,.Vol.1 (26), 28-33 (in Ukrainian).

7. Nastyuk M. H., Ivanova.N.O., Nthadailova T.M., Samoilenko N.A., 2013. Experience of using modern technology of hydrometric measurements in the hydrometeorological service of Ukraine. Naukovi Praci UkrNDUMI, Vol.264, 43-51 (in Ukrainian).

8. Design of River Monitoring Device with the Internet of Things Using LPWAN Based(Conference Paper), 2020. Jumhana, S.R., Azmi, F., Setianingsih, C. 2nd Interna- tional Conference on Electrical, Control and Instrumentation Engineering, ICECIE 2020; Kuala Lumpur; Malaysia; 28 November; Category numberCFP20U62-ART; Code 166393.

9. Imran, M., Sheikh Abdul Khader, P., 2020. Forecasting water level of Jhelum River of Kashmir Valley India, using prediction and earlywarning system. Geography, Environment, Sustainability. Vol.13, Iss.2, 35-42. DOI: 10.24057/2071-9388-2019-169.

10. Ali, S.A., Ashfaq, F., Nisar, E., Azmat, U., Zeb, J., 2020. A Prototype for Flood Warning and Management System using Mobile Networks. Proceedings of 2020 17th International Bhurban Conference on Applied Sciences and Technology, IBCAST 2020. January, Article number 9044531, 326-331. DOI: 10.1109/IBCAST47879.2020.9044531.

11. Moreno, C., Aquino, R., Ibarreche, J., Pérez, I., Castellanos, E., Álvarez, E., Rentería, R., Anguiano, L., Edwards, A., Lepper, P., Edwards, R.M., Clark, B., 2019. Rivercore: IoT device for river water level monitoring over cellular communications. Sensors (Switzerland). Vol.19, Iss. 1, 1 January, Article number 127. DOI: $10.3390 / \mathrm{s} 19010127$.

12. Restu Purnomo, Mahmud Hari Pamungkas, Daffa Arrofi and Abdul Goni., 2018. Flood prediction using integrated sensor based on internet of thing and radio frequency as flood risk reduction. AIP Conference Proceedings 1987, 020070; https://doi.org/10.1063/1.5047355.

13. Versatile mobile and stationary low-cost approaches for hydrological measurements, 2018. International Archives of the Photogrammetry, Remote Sensing and Spatial Information Sciences. ISPRS Archives, 42 (2), 543-550.

14. UI Islam, R., Andersson, K., Hossain, M.S., 2015. A web based belief rule based expert system to predict flood. 17th International Conference on Information Integration and WebBased Applications and Services, WAS 2015, Brussels, Belgium, 11 December. DOI: 10.1145/2837185.2837212.

15. Ultrasonic Transducers XPS10/15F., 2013. Operating Instructions: Siemens (A5E32725813) 08, 28.

16. Ultrasonic controllers MultiRanger 100/200., 2019. Operating Instructions: Siemens (7ML19985FB06, rev 6.2), 282.

17. Zamikhovskyi L. M., Nykolaychyk M.Ya., 2018. Hardware and software complex for parameterization and commissioning of Smartconverters for automated process control systems. An intellectual product of scientists, inventors and innovators of the Carpathian 
region. An annual catalog of the most significant inventions, utility models, industrial designs and rationalization proposals, 30-33 (in Ukrainian).

18. Nykolaychyk M.Ya., 2018. Hardware and software complex for remote parameterization of smart-converters as part of the APCS. Collection of abstracts of the XIV international conference Control and management in complex systems. Vinnitsa, 15-17.10.2018 (in Ukrainian).

19. Dolphin Plus. (2002). Instrument configuration software. Siemens Milltronics, 9.

20. S7-1200 Programmable controller, 2019. System Manual: Siemens (A5E02486680-AN, V4.4), 1542.

\section{Тенденции развития систем мониторинга состояния водных объектов и разработка ГИС-Днестр на базе промышленного ИВТ}

\section{Леонид Замиховский, Елена Замиховская, Николай Николайчук, Иван Левиикий}

Аннотация. В работе показано, что недостаточное и несвоевременное гидрологическое прогнозирование уровня развития наводнений приводит к ежегодным значительный экономический ущерб и человеческие жертвы. Последнее требует постоянного контроля и мониторинга состояния водных объектов, что возможно при наличии современных автоматизированных систем контроля и мониторинга. Проведенный анализ показал, что информационно-измерительные системы (АИИС) контроля паводковых вод, эксплуатируемых в Украине, их количество, стоимость и технические характеристики не обеспечивают получения необходимой для прогнозирования развития наводнений информации.
Анализ тенденций развития систем автоматизированного контроля и мониторинга состояния водных объектов показал, что современные зарубежные системы, которые находятся на стадии разработки или апробации основанные на использовании микроконтроллеров, «smart»преобразователи физических величин, современных систем связи и технологии Интернет вещей, а также использовании смартфонов с камерой Raspberry Pi для определения уровня воды в реках.

Приводится разработка с использованием промышленного Интернет вещей базового варианта геоинформационной системы контроля и мониторинга состояния водных объектов ГИСДнестр. Рассматриваются структура, компоненты и функции ГИС-Днестр. Решаются задачи по организации аппаратно программных средств для параметрирования и диагностики «smart»-преобразователи, налаживание коммуникационной среды промышленной связи, разработки алгоритмов сбора, обработки и передачи данных, исследования характеристик измерительных сигналов. приводятся результаты исследования эхо-профилей ультразвукового сенсора уровня XPS10 со «smart» - преобразователи Multiranger 100, а также процедура работы с ГИС-Днестр. Использование разработанной ГИС-Днестр показало ее эффективность и надежность в работе. 